DOI: https://doi.org/10.32839/2304-5809/2021-5-93-64

удК 342.5

Рибалкін А.О., Седих Ю.О.

Дніпропетровський державний університет внутрішніх справ

\title{
СИСТЕМА СУДОВОЇ ВЛАДИ В УКРАЇНІ ТА ІІЇ РОЛЬ У РОЗБУДОВІ ПРАВОВОЇ ДЕРЖАВИ
}

Анотація. У статті здійснено теоретико-правовий аналіз діяльності органів судової влади у процесі реформації. Визначено конституційно-правові особливості роботи органів судової влади у сучасних умовах. Досліджено зміни, внесені до організації роботи судів внаслідок реформування інституту. Визначено місце судів загальної юрисдикції у системі охорони і захисту прав та свобод людини і громадянинав Україні. Наголошено, що суди мають фундаментальне значення для формування та розвитку демократичної, правової та соціальної держави. Актуалізовано, що реформаційні процеси у сфері судоустрою повинні бути спрямовані на підвищення ролі громадянського суспільства, що забезпечить підвищення довіри до органів судової влади та державних органів в цілому. Визначено, що судові органи сприяють вирішенню найбільш важливих завдань, що виникають перед правовою державою, таких, як захист прав і свобод людини, підтримання режиму правової законності у сфері управління і стабілізацї̈ державної влади. У своїй діяльності судові органи знаходяться в постійній взаємодії з законодавчими та виконавчими органами, і у зв'язку з цим потрібно наукове осмислення і законодавче закріплення способів і меж відповідної взаємодії.

Ключові слова: правосуддя, суд, реформа судоустрою, правова держава, громадянське суспільство.

Rybalkin Andrii, Siedykh Yuliia

Dnipropetrovsk State University of Internal Affairs

\section{THE JUDICIARY SYSTEM IN UKRAINE AND ITS ROLE IN THE DEVELOPMENT OF THE RULE OF LAW}

Summary. The article provides a theoretical and legal analysis of the activities of the judiciary in the reform process. The constitutional and legal features of the work of the judiciary in modern conditions are determined. The main goals and ob-jectives of the judiciary in Ukraine are the reliable protection of human and civil rights and fundamental freedoms. Its implementation can be ensured only by a pro-fessional and competent court, whose representatives are able to fulfill their obliga-tions impartially, openly and transparently. The changes made to the organization of the work of courts as a result of the reform of the institute are studied. The place of courts of general jurisdiction in the system of protection and defense of human and civil rights and freedoms in Ukraine has been determined. It is emphasized that the courts are fundamental structures for the formation and development of a democratic, legal and social state. It is emphasized that the reform processes in the field of the judiciary should be aimed at increasing the role of civil society, which will increase confidence in the judiciary and public authorities in general. It is determined that the judiciary contributes to the solution of the most important tasks facing the rule of law, such as the protection of human rights and freedoms, maintaining the rule of law in the field of governance and stabilization of state power. In their activities, the judiciary is in constant interaction with the legislature and the executive, and in this regard requires scientific understanding and legislative consolidation of ways and limits of appropriate interaction. It is stated that the judiciary provides and guarantees a stable connection between the state and civil society, promotes real, effective inclusion of citizens in the mechanism of state lawmaking. The concretization of the position and role of the court in modern society is becoming a landmark question, the answer to which depends, inter alia, on the fact that courts actively involve in cases other than analysis of regulations, other factors and circumstances that characterize the real social context and values recognized by society at a particular historical stage.

Keywords: justice, court, judicial reform, rule of law, civil society.

$\Pi^{2}$ остановка проблеми. Одним із головних завдань судової реформи сьогодні є реалізація демократичних ідей правосуддя, які були вироблені протягом багатьох років теоретиками та практиками. У цьому аспекті особливого значення набуває розробка концептуальних основ судової системи України. Роль суду є одні$є ю$ із вирішальних в забезпеченні прав і законних інтересів людини і громадянина. Здійснення правозахисної функції є важливою гарантією реалізації, охорони та захисту демократичних цінностей у суспільстві та державі.

Право на справедливий та незалежний суд $€$ одним $з$ фрундаментальних у діяльності судової гілки влади, оскільки наслідком реалізації зазначеного принципу, формуеться довіра та повага до органів судової влади, підвищуться правова свідомість та культура населення. Основними цілями і завданнями судової влади в Україні $€$ надійний захист прав і основних свобод людини і громадянина. Його реалізацію здатний забезпечити тільки професійний і компетентний суд, представники якого здатні виконувати покладені на них зобовязання неупереджено, відкрито та прозоро, стежити на соціальною едективніст інституту та підвищувати його авторитетність серед органів публічної влади.

Аналіз останніх досліджень і публікацій. Наукові положення про сут-ність та зміст функцій і повноважень, організації діяльності органів судової влади були досліджені у роботах вчених, серед яких: В. Авер'янов, С. Алексеєв, М. Баглай, Д. Бахрах, А. Венгеров, М. Вітрук, Л. Воєводін, А. Георгіц, В. Гергелійник, В. Горшеньов, Л. Коваль, О. Козлов, А. Колодій, В. Копєйчиков, М. Корнієнко, М. Мітюков, Ю. Тодика, Б. Топор- 
нін, В. Шаповал, Ю. Шемшученко, Х. Штайнбергер, Н. Шукліна, Ю. Шульженко, В. Яворський та ін. Однак незважаючи на значну кількість наукових розробок, питання судової системи України потребує підвищеної уваги та нових науковообгрунтованих концепцій розвитку.

Виокремлення невирішених раніше частин загальної проблеми. У статті проаналізовано роль судової гілки влади у розбудові правової держави на сучасному етапі розвитку суспільства і держави.

Мета статті полягає у здійсненні теоретикопраововго аналізу системи судової влади в Україні, визначення їі місця у механізмі розбудови праової держави.

Виклад основного матеріалу. У процесі розбудови правової та держави, одним 3 найголовніших критеріїв є створення прозорої, некорумпованої та ефрективної судової влади, оскільки від зазначених критеріїв залежить якісний захист прав і свобод людини і громадянина. Нині перед нами постає питання у зміні та впровадженні нової судової системи та редрормування окремих інститутів, тому що без цього не може існувати демократична держава.

Конституційно-правову основу діяльності суддів складають, насамперед, конституційні норми права, що закріплені у розділі VIII Основного Закону «Правосуддя». Більш детально засади організащії судової влади та засади здійснення правосуддя в Україні визначені в Законі України «Про судоустрій і статус суддів». Також це й інші законодавчі та підзаконні нормативно-правові акти, що визначають нормативно-правові та організаційно-правові засади фрункіонування судової системи та діяльності суддів [1, с. 96]. Відповідно, суддя $є$ основним носіем судової влади, вивчення конституційно-правового статусу якого визначатиме його сутність і соціальне призначення.

Відповідно до ст. 1 Конституції України, наша країна є правовою державою, в якій судова влада є самостійною, незалежною гілкою влади в системі ї̈ поділу. Тому постає питання щодо пошуку оптимальної моделі правового статусу судової влади, оскільки ця гілка влади є запорукою справжньої інституційно-фрункціональної правової державної влади [7].

Одним 3 основних ознак правової держави є здійснення принщипу поділу влади. Судова влада, згідно з принципом поділу державної влади, є однією з їі гілок. Відповідно на судову владу поширюються всі характеристики та ознаки державної влади: верховенство, тобто суверенність, повнота, неподільність, самостійність, формальна незалежність від влади будь-якої організації або особи, а також здійснення від імені держави iï органами, поширення влади на всіх членів суспільства, наявність у розпорядженні механізму для реалізації своїх завдань і фрункцій [12, с. 85].

Судова влада - відносно самостійна, легітимна, універсальна, легальна складова державної влади, що має імперативні характеристики та контрольні повноваження щодо інших складових державної влади, і забезпечує регулю-вання визначеного кола суспільних відносин на основі сорормованих доктринальних положень про правову державу та трискладову теорію державної влади у відповідних фрормах та конкретно вста- новленими методами, що грунтуються на змісті ознак її едності та особливості правовідносин [15, с. 117]. Здійснюючи свої фрункщії, судові органи сприяють вирішенню найбільш важливих завдань, що виникають перед правовою державою, таких, як захист прав і свобод людини, підтримання режиму правової законності у сорері управління і стабілізації державної влади. У своїй діяльності судові органи знаходяться в постійній взаємодії з законодавчими та виконавчими органами, і у зв'язку 3 цим потрібно наукове осмислення і законодавче закріплення способів і меж відповідної взаємодії [6, с. 69-73]. До того ж, зі всіх гілок влади судова влада може бути найбільш близькою до народу, оскільки переводить абстрактну суспільну користь законів у площину конкретних приватних інтересів.

Відокремлення судової гілки влади від інших державно-владних структур свідчить про серйозний поступ держави до реалізації принципу верховенства права, закріплених у ньому ідей свободи і справедливості. Без здійснення основної діяльності судової влади - охорони членів суспільства від свавілля громадян, самої держави, їі органів і посадових осіб - держава не може вважатися правовою.

Основною тенденцією розвитку сучасних фонкцій держави є саморегулювання, самоорганізація та самоврядування [5, с. 68]. Практична реалізація судової влади і повноважень визначає їі місце у механізмі державної влади та в політичній системі. Виходячи 3 цього, можна зазначити те що, привласнення повноважень суду є найнебезпечнішою формою посягання на державний лад. Завдання судової влади в Україні полягає в тому, щоб шляхом розгляду та вирішення справ забезпечувати певний баланс між свободою в суспільстві 3 обов'язком виконання та дотримання законів.

Основною метою судової реформи є формування судової влади, створення нового адаптованого законодавства та удосконалення форм судочинства, де буде прослідковуватись розмежування повноважень органів державної влади та забезпечення незалежності судових органів, реалізація демократичних ідей правосуддя, виробленої світовою практикою й наукою; забезпечення ефрективної спеціалізації судів, серед яких повинні бути обов'язково господарські суди; чітке визначення компетенції різних учасників судової системи тощо [14, с. 82$]$.

Відповідно до засад організації судової влади в Україні, судова влада забезпечуе розвиток суспільства і держави шляхом здійснення правосуддя цивільного, господарського, адміністративного, кримінального, а також конституційного форм судочинства [1, с. 110]. Правосуддя, як зазначалося раніше, в Україні здійснюеться виключно судами [9, с. 82]. Суд, реалізує фрункцію правосуддя на засадах верховенства права, забезпечуе захист гарантованих Конституцією та законами України прав і свобод людини і громадянина, прав і законних інтересів юридичних осіб, інтересів суспільства і держави.

Варто також звернути увагу на проблему розширення участі громадян у здійсненні правосуддя. Сьогодні народ відсторонений від участі у здійсненні правосуддя по переважній більшос- 
ті кримінальних і цивільних справ та у всіх адміністративних справах. Хоча в адміністративних справах участь народу є необхідною для забезпечення балансу державних і суспільних інтересів. Слід погодитись із думкою I. Гриценка, що недержавний контроль $є$ одним із механізмів позитивної консолідації суспільства, коли максимально можлива відкритість судової влади стає запорукою підвищення рівня їі довіри серед широких верств населення, коли відносини між державою та громадянським суспільством розвиваються в руслі конструктивного діалогу [3, с. 243]. Через відповідні механізми суспільство повинно впливати на організацію суддівського корпусу.

Вплив суспільства також реалізуеться при здійсненні правосуддя через безпосередню участь його представників (народних засідателів, присяжних). Рівновазі між суспільством та державою сприяе адвокатура як незалежна пра-возахисна інституція громадянського суспільства, що має стати важливою опорою самостійності судової влади. Крім того, громадянський контроль за судовою владою повинен здійснюватися через відкритість процесу правосуддя (гласність та відкритість судочинства), доступність 3МI до судової інформації та її об'єктивне висвітлення [8].

Варто підкреслити, що рівень довіри громадськості до органів судової влади є незадовільним (за результатами дослідження, проведеного соціологічною службою Центру Разумкова з 6 по 11 вересня 2019 року, недовіра найчастіше висловлювалась судовій системі загалом - 72\%, прокуратурі - 61\% [13]). Цей аспект є одним із визначальних для продовження редормаційного процесу в судовій гілці влади. Сьогодні внесено зміни до деяких законодавчих актів, зокрема через положення Закону України «Про внесення змін до Закону України «Про судоустрій і статус суддів» та деяких законів України щодо діяльності органів суддівського врядування» від 16 жовтня 2019 року № 193-IX [11] та Закону України «Про внесення змін до деяких законодавчих актів України щодо першочергових заходів із редорми органів прокуратури» від 19 вересня 2019 року № 113-IX [10]. Таким чином, можна констатувати зростання показнику недовіри до судової системи та прокуратури попри заходи, спрямовані на реформування цих інституцій 3 метою підвищення їхньої легітимності, як одним із визначальних викликів реформування системи правосуддя в Україні на сучасному етапі.
Роль суду загальної юрисдикції у здійсненні правосуддя зумовлена високим суспільним призначенням суду i особливістю характеру здійснення своєї діяльності, необхідністю справедливогоправосуддя.Відповіднодоадміністративнотериторіального поділу держави судову систему України поділено, згідно зі ст. 125 Конституції України, за принципами територіальності, спеціалізації та інстанційності. В свою чергу ст. 17 Закону України «Про судоустрій і статус суддів» від 02.06.2016 р. [11] крім принципів побудови системи судів загальної юрисдикції - територіальності, спеціалізації та інстанційності, визначає судові ланки [4, с. 74]. Так, за змістом вказаної статті систему судоустрою складають: 1) місцеві суди; 2) апелящійні суди; 3) Верховний Суд. До того ж, для розгляду окремих категорій справ створено Вищі спеціалізовані суди, які здійснюють правосуддя як суди першої інстанції у справах, визначених процесуальним законом. Верховний Суд здійснюе правосуддя як суд касаційної інстанщії, а у випадках, визначених процесуальним законом, як суд першої або апеляційної інстанції, в порядку, встановленому процесуальним законом.

Висновки. Отже, у процесі розбудови правової держави одним з їі найбільш важливих критеріїв є створення прозорої та ефективної судової влади. Наразі назріла необхідність докорінних змін судової системи та реформування окремих інститутів. Для реалізащії зазначених положень, в Україні триває реформа судової влади, яка трансформуе систему органів та рорядок їх роботи. Загалом, значення судів загальної юрисдикції у здійсненні правосуддя зумовлене високим суспільним призначенням суду і особливим характером судової діяльності, необхідністю справедливого правосуддя.

Особливе значення в контексті європейської інтеграції має адаптивність національного законодавства України до европейских стандартів. Проблема вдосконалення вітчизняного правосуддя має першочергове значення для суспільства і держави. Інтегрування європейської методології удосконалення системи судової влади залишається однією з ключових умов формування незалежної, прозорої та ефрективної судової системи, а забезпечення користувачів суду якісними послугами, на підставі досвіду інших держав забезпечуе швидке і едективне вирішення спорів, які сприятимуть підвищенню довіри громадян до суду, що є запорукою демократичного суспільства.

\section{Список літератури:}

1. Байрачна Л.К. Конституційне право України : підручник. Харків : Право, 2008. 416 с.

2. Гриценко I.C., Прилуцький С.В. Судова влада і громадянське суспільство: концепт взаємодії. Вісник крилінального судочинства. 2015. № 1. С. 241-249.

3. Зайчук О.В. Сучасна правова енциклопедія. Ін-т законодавства Верховної Ради України. Київ : Юрінком Інтер, 2013. 408 c.

4. Кельман М.С., Мурашин О.Г., Хома Н.М. Загальна теорія держави та права. Львів : Новий Світ-2000, 2003.584 с.

5. Кобликов С.А. Судебная политика и способы её реализации. Советское государство и право. 1991. № 6. С. 69-73.

6. Конституція України від 28 червня 1996 р. № 30 (зі змінами і допов.). Відолості Верховної Ради України. 2019. № 38. Ст. 160.

7. Короед С.О., Кресіна І.О., Прилуцький С.В. Концепщія реформування судової влади України. Судова апеляція. 2015. № 3. C. 6-34.

8. Притика Д.М. Створення науково обгрунтованої системи правосуддя в Україні - головна мета судової реформи. Право України. 2009. № 12. С. 71-84.

9. Про внесення змін до деяких законодавчих актів України щодо першочергових заходів із рефрорми органів прокуратури» : Закон України від 19 вересня 2019 року № 113-IX. Відолості Верховної Ради України. 2019. № 42. Ст. 238 . 
10. Про судоустрій і статус суддів» та деяких законів України щодо діяльності органів суддівського врядування : Закон України від 16 жовтня 2019 року № 193-IX. Відолості Верховної Ради Украӥни. 2019. № 50. Ст. 354.

11. Рабінович П.М. Державна влада. Юридична енциклопедія. Київ : Право, 1999. 380 с.

12. Рівень довіри до суспільних інститутів та електоральні орієнтації громадян України. URL: http://razumkov.org.ua/ napriamky/sotsiologichni-doslidzhennia/rivendoviry-do-suspilnykh-instytutiv-ta-elektoralni-oriientatsii-gromadian-ukrainy

13. Система публічного управління в умовах децентралізації влади: механізми горизонтальної взаємодії : монографія / Л. Приходченко, С.Є. Саханєнко, П.І. Надолішній та ін. ; за заг. ред. Л.Л. Приходченко. Одеса : ОРІДУ НАДУ, 2017. 332 с.

14. Теоретико-правові засади розвитку та фрункціонування судової влади : монографія / М.С. Булкат ; НАН України, Ін-т держави і права ім. В.М. Корецького. Київ : Юрид. думка, 2018. 502 с.

\section{References:}

1. Bairachna L.K. (2008) Constitutional law of Ukraine: textbook. Kharkiv: Law, 416 p.

2. Hrytsenko I.S., Prylutskyi S.V. (2015) Judiciary and civil society: the concept of interaction. Bulletin of criminal proceedings, no. 1, pp. 241-249.

3. Zaichuk O.V. (2013) Modern legal encyclopedia. Institute of Legislation of the Verkhovna Rada of Ukraine. Kyiv: Yurinkom Inter, 408 p.

4. Kelman M.S. (2003) General theory of state and law. Lviv: New World-2000, 584 p.

5. Koblykov S.A. (1991) Judicial policy and ways of its implementation. Soviet state and law, no. 6, pp. 69-73.

6. The Constitution of Ukraine of June 28, 1996 № 30. Information of the Verkhouna Rada of Ukraine. 2019. № 38. Art. 160.

7. Koroied S.O., Kresina I.O., Prylutskyi S.V. (2015) The concept of reforming the judiciary of Ukraine. Court appeal, no. 3, pp. 6-34.

8. Prytyka D.M. (2009) Creating a scientifically sound system of justice in Ukraine is the main goal of judicial reform, no. 12 , pp. $71-84$.

9. On Amendments to Certain Legislative Acts of Ukraine Concerning Priority Measures to Reform the Prosecutor's Office": Law of Ukraine of September 19, 2019 № 113-IX. Information of the Verkhouna Rada of Ukraine. 2019. № 42. Art. 238.

10. On the Judiciary and the Status of Judges and some laws of Ukraine on the activities of judicial authorities: Law of Ukraine of October 16, 2019 № 193-IX. Information of the Verkhovna Rada of Ukraine. 2019. № 50. Art. 354.

11. Rabinovych P.M. (1999) State power. Legal Encyclopedia. Kyiv: Law, 380 p.

12. The level of trust in public institutions and electoral orientations of the citizens of Ukraine. URL: http://razumkov.org.ua/ napriamky/sotsiologichni-doslidzhennia/rivendoviry-do-suspilnykh-instytutiv-ta-elektoralni-oriientatsiigromadian-ukrainy

13. Prykhodchenko L., Sakhanienko S., Nadolishnii P. (2017) The system of public administration in the context of decentralization of power: mechanisms of horizontal interaction. Odessa: ORIDU NADU, $332 \mathrm{p}$.

14. Bulkat M.S. Theoretical and legal principles of development and functioning of the judiciary. Kyiv: Jurid. opinion, $502 \mathrm{p}$. 